The White Negress 



\section{The White Negress}

Literature, Minstrelsy, and the Black-Jewish Imaginary

LORI HARRISON-KAHAN

Rutgers University Press

NEW BRUNSWICK, NEW JERSEY, AND LONDON 
Copyright $(2011$ by Lori Harrison-Kahan. All rights reserved

No part of this book may be reproduced or utilized in any form or by any means, electronic or mechanical, or by any information storage and retrieval system, without written permission from the publisher. Please contact Rutgers University Press, 100 Joyce Kilmer Avenue, Piscataway, NJ 08854-8099. The only exception to this prohibition is "fair use" as defined by U.S. copyright law.

Visit our Web site: http://rutgerspress.rutgers.edu

Manufactured in the United States of America

\section{LIBRARY OF CONGRESS CATALOGING-IN-PUBLICATION DATA}

Harrison-Kahan, Lori.

The white negress : literature, minstrelsy, and the black-Jewish imaginary / Lori Harrison-Kahan.

p. cm. - (American Literatures Initiative)

Includes bibliographical references and index.

ISBN 978-0-8135-4782-4 (alk. paper)

ISBN 978-0-8135-4783-1 (pbk. : alk. paper)

1. American literature-2oth century-History and criticism. 2. Passing (Identity) in literature. 3. Women and literature-United States-History-2oth century. 4. Ethnicity in literature. 5. African American women authors.

6. Jewish women authors-United States. 7. Americanization. 8. Immigrants in literature. I. Title.

$\mathrm{PS}_{228 .} \mathrm{P}_{35} \mathrm{H}_{37} 2010$

$810.9629-\mathrm{dc} 22$

2010008515

A British Cataloging-in-Publication record for this book is available from the British Library.

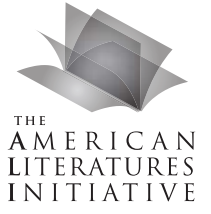

A book in the American Literatures Initiative (ALI), a collaborative publishing project of NYU Press, Fordham University Press, Rutgers University Press, Temple University Press, and the University of Virginia Press. The Initiative is supported by The Andrew W. Mellon Foundation. For more information, please visit www.americanliteratures.org. 